\title{
Cellular Localizations of AMPA Glutamate Receptors within the Basal Forebrain Magnocellular Complex of Rat and Monkey
}

\author{
Lee J. Martin, ${ }^{1,4}$ Craig D. Blackstone, 5 Allan I. Levey, ${ }^{2,4, a}$ Richard L. Huganir, ${ }^{3,5}$ and Donald L. Price ${ }^{1,2,3,4}$ \\ Departments of 'Pathology, ${ }^{2}$ Neurology, and ${ }^{3}$ Neuroscience, ${ }^{4}$ the Neuropathology Laboratory, and ${ }^{5}$ the Howard Hughes \\ Medical Institute, The Johns Hopkins University School of Medicine, Baltimore, Maryland 21205-2196
}

The cellular distributions of $\alpha$-amino-3-hydroxy-5-methyl-4isoxazole propionic acid (AMPA) receptors within the rodent and nonhuman primate basal forebrain magnocellular complex (BFMC) were demonstrated immunocytochemically using anti-peptide antibodies that recognize glutamate receptor (GluR) subunit proteins (i.e., GluR1, GluR4, and a conserved region of GluR2, GluR3, and GluR4c). In both species, many large GluR1-positive neuronal perikarya and aspiny dendrites are present within the medial septal nucleus, the nucleus of the diagonal band of Broca, and the nucleus basalis of Meynert. In this population of neurons in rat and monkey, GluR2/3/4c and GluR4 immunoreactivities are less abundant than GluR1 immunoreactivity. In rat, GluR1 does not colocalize with ChAT, but, within many neurons, GluR1 does colocalize with GABA, glutamic acid decarboxylase (GAD), and parvalbumin immunoreactivities. GluR1and GABA/GAD-positive neurons intermingle extensively with ChAT-positive neurons. In monkey, however, most GluR1immunoreactive neurons express ChAT and calbindin-D28 immunoreactivities. The results reveal that noncholinergic GABAergic neurons, within the BFMC of rat, express AMPA receptors, whereas cholinergic neurons in the BFMC of monkey express AMPA receptors. Thus, the cellular localizations of the AMPA subtype of GluR are different within the BFMC of rat and monkey, suggesting that excitatory synaptic regulation of distinct subsets of BFMC neurons may differ among species. We conclude that, in the rodent, BFMC GABAergic neurons receive glutamatergic inputs, whereas cholinergic neurons either do not receive glutamatergic synapses or utilize GluR subtypes other than AMPA receptors. In contrast, in primate, basal forebrain cholinergic neurons are innervated directly by glutamatergic afferents and utilize AMPA receptors.

[Key words: AMPA receptor, excitatory amino acids, magnocellular preoptic nucleus, medial septal nucleus, nucleus basalis of Meynert, substantia innominata]

\footnotetext{
Received Aug. 14, 1992; revised Nov. 23, 1992; accepted Dec. 3, 1992.

We thank Ms. Judith Van Lare and Mr. Wayne Voris for their excellent technical assistance, Dr. Linda Cork for providing monkey tissue, and the Baltimore Zoological Society for their cooperation. This work was supported by grants from the U.S. Public Health Service (NIH NS 20471) and the Howard Hughes Medical Institute. D.L.P. is the recipient of Javits Neuroscience Investigator Award NIH NS 10580 and Leadership and Excellence in Alzheimer's Disease (LEAD) Award NIA AG 07914

Correspondence should be addressed to Lee J. Martin, Ph.D., Neuropathology Laboratory, The Johns Hopkins University School of Medicine, 558 Ross Research Building, 720 Rutland Avenue, Baltimore, MD 21205-2196.

a Present address: Department of Neurology, Emory University, Atlanta, GA 30322.

Copyright (c) 1993 Society for Neuroscience $0270-6474 / 93 / 132249-15 \$ 05.00 / 0$
}

L-Glutamate and L-Aspartate are the major known excitatory neurotransmitters in the mammalian brain (Fagg and Foster, 1983; Fonnum, 1984), and several lines of evidence suggest that neurons within the basal forebrain magnocellular complex (BFMC) receive excitatory glutamatergic or aspartergic innervation from a variety of regions. Cultured cells from the BFMC are depolarized rapidly by glutamate (Nakajima et al., 1985). Biochemical (Walaas and Fonnum, 1980; Fibiger and Lehmann, 1981; Davies et al., 1984), autoradiographic (Monaghan and Cotman, 1982; Halpain et al., 1984; Monaghan et al., 1984), and connectional (Mesulam and Mufson, 1984; Lemann and Saper, 1985; Fuller et al., 1987; Carnes et al., 1990; Gaykema et al., 1991) studies indicate that neurons in the BFMC are innervated by glutamatergic or aspartergic inputs from cerebral cortex, amygdala, thalamus, hypothalamus, and brainstem. Corticofugal axon terminals contact BFMC neurons, but transmitter phenotypes of pre- and postsynaptic elements have not been identified (Lemann and Saper, 1985). Moreover, amygdalofugal axons terminate on cholinergic basal forebrain neurons, but the transmitter of these terminals is also not known (Záborszky et al., 1984). Thus, the precise origin of glutamatergic and aspartergic inputs to the BFMC and neuronal targets of these afferents to the basal forebrain are not well defined, although possible targets of acidic amino acid-utilizing afferents include cholinergic and GABAergic neurons (Köhler et al., 1984; Brashear et al., 1986; Walker et al., 1989; Gulyás et al., 1991).

Glutamatergic innervation that rapidly depolarizes cells is mediated by ligand-gated ion channel receptors that are classified into pharmacologically and electrophysiologically distinct subtypes: NMDA receptors, kainate (KA) receptors, and $\alpha$-amino-3-hydroxy-5-methyl-4-isoxazole-propionic acid (AMPA) receptors (Monaghan et al., 1989; Watkins et al., 1990; Gasic and Heinemann, 1991). These glutamate-gated ion channel receptors are oligomers, probably pentamers, of homologous subunits (Blackstone et al., 1992b; Wenthold et al., 1992). Molecular cloning has identified four NMDA receptor subunits (NMDAR 1, 2A, 2B, and 2C) and nine non-NMDA ionotropic glutamate receptor (GluR) subunits (GluR1-GluR7, KA1, and KA2) as well as several variants generated by alternate splicing (Hollmann et al., 1989; Bettler et al., 1990; Boulter et al., 1990; Keinänen et al., 1990; Sommer et al., 1990; Egebjerg et al., 1991; Moriyoshi et al., 1991; Werner et al., 1991; Bettler et al., 1992; Gallo et al., 1992; Herb et al., 1992; Monyer et al., 1992). GluR1-GluR4 (also known as GluR-A through GluR-D) are the major AMPA receptor subunits; GluR5-GluR7, KA1, and KA2 are believed to be KA receptor subunits.

Using antibodies that specifically detect divergent amino acid sequences of individual subunits of the AMPA-preferring GluR, 


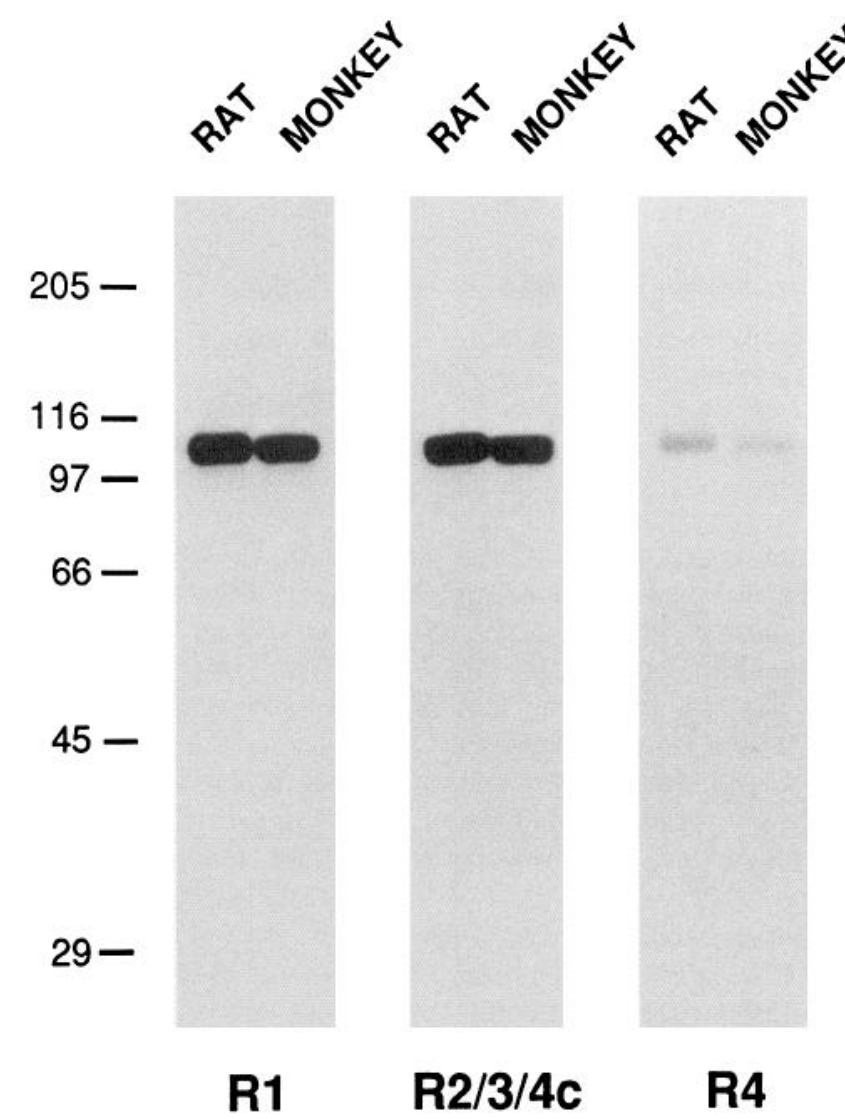

Figure 1. Specificity of anti-peptide antibodies to GluR subunits. Total basal forebrain homogenates ( $50 \mu \mathrm{g}$ protein/lane) from rat and monkey brains were subjected to SDS-PAGE and immunoblotted with antibodies $(0.5 \mu \mathrm{g} \mathrm{IgG/ml)}$ to GluR1 $(R I)$, GluR2/3/4c $(R 2 / 3 / 4 c)$, and GluR4 $(R 4)$. Immunoreactive proteins were detected with enhanced chemiluminescence. Because exposure times were varied to emphasize the specificity of each preparation, quantitative comparisons between the amount of protein detected with each of the antibodies were not possible. Sizes of molecular weight standards (in $\mathrm{kDa}$ ) are indicated at left.

it is now possible to begin to characterize the precise cellular distributions of specific molecular subtypes of GluR in the brain (Rogers et al., 1991; Blackstone et al., 1992b; Martin et al., 1992; Petralia and Wenthold, 1992; Price et al., 1992). The aims of this immunocytochemical study were threefold: to evaluate, using light and electron microscopy, whether AMPA receptors are expressed by neurons within the BFMC; to identify the neuronal phenotype of cells that express AMPA receptors; and to determine whether species differences exist in the cellular localization of AMPA receptors within the BFMC of rodents and primates. Our results demonstrate that (1) subsets of neurons within the BFMC express AMPA receptors, (2) the major AMPA receptor subunits are expressed differentially in these neurons, and (3) the cellular localizations of the AMPA receptor subunit GluR1 are different in rodents and primates. Neurons in the basal forebrain of rodents (Hepler et al., 1985; Wenk et al., 1989; Wozniak et al., 1989), monkeys (Aigner et al., 1987) and, possibly, humans (Schwarcz and Price, 1991) are vulnerable to excitotoxic injury, and it has been postulated that GluR-mediated excitoxicity provides a mechanism leading to the death of nerve cells in individuals with Alzheimer's disease (Choi, 1988; Greenamyre and Young, 1989; McGeer, 1989), a neurodegenerative disease characterized by loss of cholinergic neurons in the BFMC (Whitehouse et al., 1981). Thus, the delineation of the in vivo cellular expression of GluR subtypes in the BFMC should provide insights into the functional organization of this region in health and disease.

\section{Materials and Methods}

Gel electrophoresis and immunoblotting. Basal forebrains were dissected from adult male Sprague-Dawley rats (150-175 gm) and an adult rhesus monkey and were immediately frozen at $-70^{\circ} \mathrm{C}$. For preparation of total homogenates, tissues were homogenized with a Brinkmann Polytron in $20 \mathrm{~mm}$ Tris- $\mathrm{HCl}(\mathrm{pH} 7.4)$ containing $10 \%$ sucrose $(\mathrm{w} / \mathrm{v}), 20$ $\mathrm{U} / \mathrm{ml}$ of Trasylol (aprotinin), $20 \mu \mathrm{g} / \mathrm{ml}$ of pepstatin A, $20 \mu \mathrm{g} / \mathrm{ml}$ of chymostatin, $0.1 \mathrm{~mm}$ phenylmethylsulfonyl fluoride, $10 \mathrm{~mm}$ benzamidine, $1 \mathrm{~mm}$ EDTA, and 5 mм EGTA. Homogenates were subjected to SDS-polyacrylamide gel electrophoresis ( $8 \%$ polyacrylamide gels), transferred to polyvinylidene fluoride (PVDF) membrane (Immobilon P; Millipore, Bedford, MA) by electroblotting ( $30 \mathrm{~V}$, overnight), and immunoblotted with antibodies to GluR1, an epitope common to GluR2, GluR3, and GluR4c (denoted GluR2/3/4c), and GluR4 as described previously (Blackstone et al., 1992b).

Immunocytochemistry. Adult (300-400 gm) male and female Sprague-Dawley rats $(n=9)$, adult rhesus monkeys $(n=3)$, and an adult lion-tailed macaque (Macaca silenus) were used in this study. Some rats $(n=3)$ received bilateral intracerebroventricular injections of colchicine (70-120 $\mu \mathrm{g}$ ) and were killed $48 \mathrm{hr}$ later. Rats and monkeys were deeply anesthetized with $4 \%$ chloral hydrate or sodium pentobarbital and perfused intraaortically with cold $0.1 \mathrm{~m}$ phosphate-buffered $0.9 \%$ saline (PBS), followed by either $4 \%$ paraformaldehyde $/ 0.1 \%$ glutaraldehyde $/ 15 \%$ saturated picric acid prepared in PBS, or $4 \%$ paraformaldehyde prepared in PBS or according to the $\mathrm{pH}$-shift protocol (Berod et al., 1981). After fixation, the brains (except for the brain of the liontailed macaque) were removed from the skull and blocked and postfixed $\left(1-2 \mathrm{hr}\right.$ at $\left.4^{\circ} \mathrm{C}\right)$. These brains were either placed in buffer or cryoprotected (overnight at $4^{\circ} \mathrm{C}$ ) in $20 \%$ glycerol/PBS and frozen in isopentane chilled by dry ice. The brain of the lion-tailed macaque was cut into 3-mmthick slabs that were postfixed $(2 \mathrm{hr})$ in $4 \%$ paraformaldehyde $/ 0.5 \%$ glutaraldehyde, transferred to $4 \%$ paraformaldehyde $/ 0.1 \%$ glutaraldehyde for overnight, and rinsed in PBS.

Coronal and sagittal sections $(40 \mu \mathrm{m})$ were cut on a sliding microtome or Vibratome and transferred to cold Tris-buffered saline (TBS) (pH 7.2). Sections were permeabilized (10-30 $\mathrm{min}$ ) in $0.4 \%$ or $0.08 \%$ Triton $\mathrm{X}-100(\mathrm{TX}) / \mathrm{TBS}$, preincubated $(1 \mathrm{hr})$ with $4 \%$ normal goat serum diluted with and without $0.1 \% \mathrm{TX} / \mathrm{TBS}$, and incubated $\left(48 \mathrm{hr}\right.$ at $\left.4^{\circ} \mathrm{C}\right)$ in affinity-purified rabbit polyclonal antibodies (concentrations of $0.5 \mu \mathrm{g}$ $\mathrm{IgG} / \mathrm{ml}$ in $2 \%$ normal goat serum/TBS, with and without $0.1 \% \mathrm{TX}$ ) that recognize GluR1, GluR4, and an epitope common to GluR2, GluR3, and GluR4c (designated as GluR2/3/4c) (Blackstone et al., 1992a,b; Martin et al., in press). As controls, some sections were incubated with (1) comparable amounts of rabbit IgG, (2) GluR antibodies preadsorbed overnight with excess $(10 \mu \mathrm{g} / \mathrm{ml})$ synthetic GluR peptide, or (3) $2 \%$ normal goat serum/TBS with primary antibodies omitted. Subsequently, sections were rinsed (30 minutes) in TBS, incubated ( $1 \mathrm{hr}$ ) with goat anti-rabbit IgG (Cappel, West Chester, PA) diluted at 1:100, rinsed (30 $\mathrm{min})$ in TBS, and incubated $(1 \mathrm{hr})$ with rabbit peroxidase-antiperoxidase (PAP) complex (Sternberger Monoclonals, Baltimore, MD) diluted at 1:200. As additional controls in some experiments, the secondary antibodies and PAP were omitted from the incubation solution. After the final incubation, sections were rinsed $(30 \mathrm{~min})$ in TBS and developed using a standard diaminobenzidine reaction.

Samples $\left(3 \mathrm{~mm}^{2}\right)$ of the basal forebrain were taken from the immunocytochemically processed Vibratome sections and treated $(1 \mathrm{hr})$ with $2 \%$ osmium tetroxide, dehydrated, stained en bloc with uranyl acetate, and flat embedded in resin on glass slides. Plastic-embedded sections were mounted on an Araldite block and cut into semithin $(1 \mu \mathrm{m})$ and thin (gold interference color) sections. Thin sections were placed on 200 mesh gold grids, stained with uranyl acylate and lead citrate, and viewed with a Philips CM12 electron microscope.

Selected sections through the rat and monkey basal forebrains were double labeled to establish whether GluR 1 colocalizes with cholinergic or GABAergic markers. Using diaminobenzidine and benzidine dihydrochloride as chromagens (Lakos and Basbaum, 1986; Levey et al., 1986), sections were stained for (1) GluR 1 and ChAT, (2) GluR1 and parvalbumin (Sigma, St. Louis, MO), (3) GluR1 and calbindin-D28, 

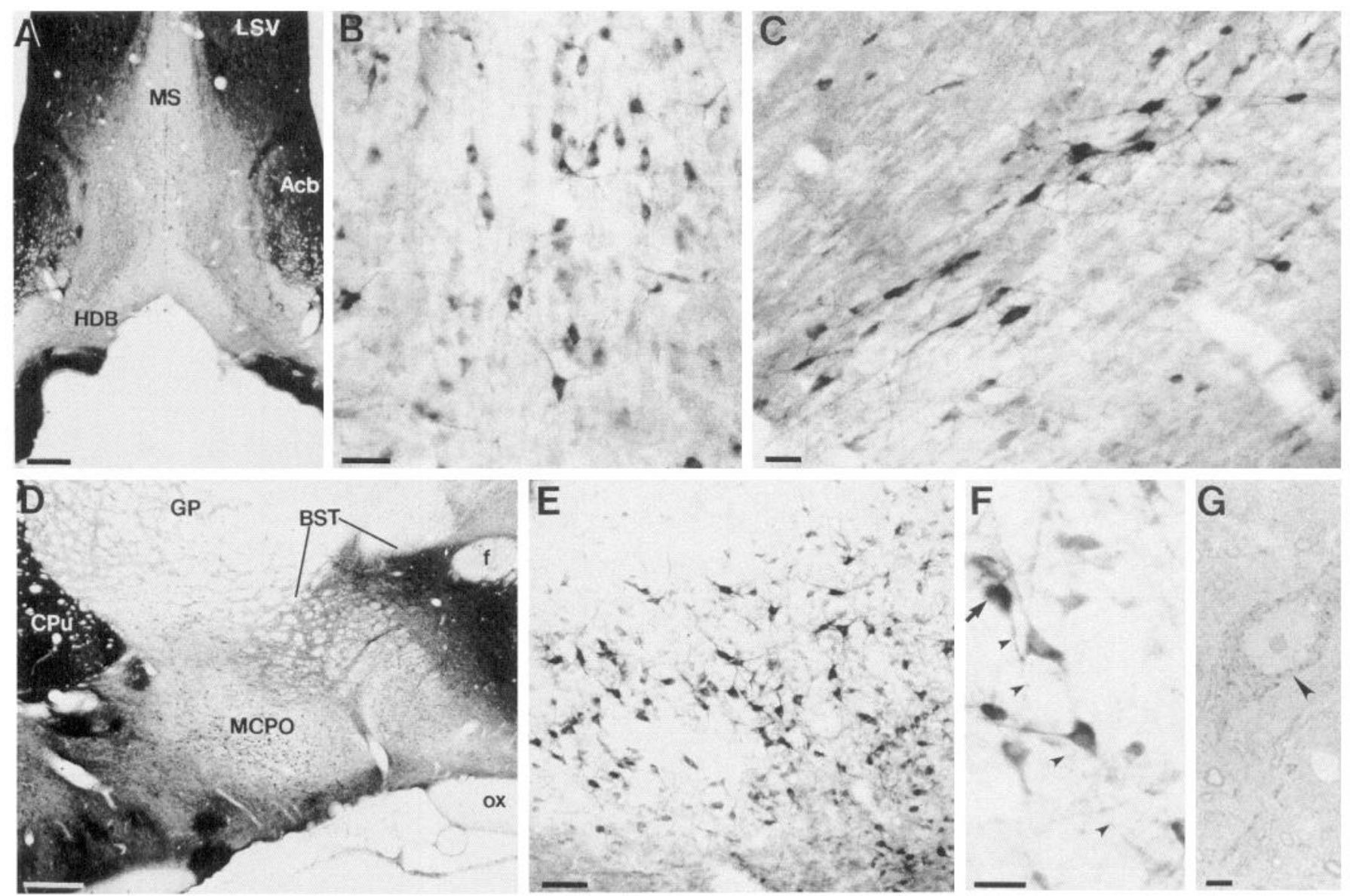

Figure 2. Cellular localization of GluR1 within the BFMC of rat. $A$, The medial septal nucleus $(M S)$ and nucleus of the horizontal limb of the diagonal band of Broca $(H D B)$ contain lower levels of GluR1 than the contiguous ventral lateral septal nucleus $(L S V)$ and nucleus accumbens $(A c b)$. Scale bar, $306 \mu \mathrm{m}$. $B$ and $C$, When viewed at higher magnification, the medial septal nucleus $(B)$ and horizontal limb of the diagonal band of Broca $(C)$ have many neuronal cell bodies and proximal dendrites that are GluR1 immunoreactive, but the neuropil in these regions shows low levels of GluR1. Scale bars: $B, 50 \mu \mathrm{m} ; C, 31 \mu \mathrm{m}$. $D$, The magnocellular preoptic nucleus $(M C P O)$ is conspicuous because of numerous GluR1immunoreactive neuronal perikarya against a background of low immunoreactivity within the neuropil. The neuropil of other forebrain structures, for example, caudate-putamen $(C P u)$ and bed nucleus of the stria terminalis $(B S T)$, is enriched in GluR1. $f$, fornix; $G P$, globus pallidus; $o x$, optic chiasm. Scale bar, $390 \mu \mathrm{m}$. E, GluR1-positive neuronal cell bodies within the magnocellular preoptic nucleus are predominantly medium to large in size and isodendritic. Scale bar, $68 \mu \mathrm{m}$. F, Aspiny dendrites (arrowheads) originating from neuronal cell bodies (arrow) within the anterior NBM can be traced for long distances. Scale bar, $26 \mu \mathrm{m}$. $G$. In plastic sections ( $1 \mu \mathrm{m}$ thick) containing components of the BFMC, GluR1-positive neuronal cell bodies (arrowhead) contain intracytoplasmic aggregates of immunoreactivity. Scale bar, $4 \mu \mathrm{m}$.

and (4) GluR1 and glutamic acid decarboxylase (GAD). In addition, some sections were incubated in the following cocktails of antibodies: rabbit anti-GluR1 (1:50) and mouse anti-ChAT (1:10) (Boehringer Mannheim, Indianapolis, IN); rabbit anti-GluR1 (1:50) and mouse anticalbindin (1:1000); guinea pig anti-GABA (1:500) (Chemicon, Temecula, CA) and rabbit anti-GluR 1; and rabbit anti-GAD (1:500) (Chemicon) and guinea pig anti-GluR1. These sections were developed using immunofluorescence. Following incubation with primary antibodies, sections were rinsed in TBS and incubated with amino-methylcoumarin-acetic acid-conjugated goat anti-rabbit IgG (Jackson, West Grove, PA) and rhodamine-conjugated goat anti-mouse IgG or goat anti-guinea pig IgG (Jackson). After several rinses in TBS, sections were mounted on slides, blow-dried, and coverslipped with DPX. Representative sections showing the distributions of GluR 1-positive and ChAT-positive neurons were plotted using a computer-assisted plotting system as previously described in detail (Martin et al., 1991).

\section{Results}

Antibodies to subunits of the AMPA receptor recognized a single band of proteins in rat and monkey brains (Fig. 1). These antipeptide antibodies to GluR1, GluR2/3/4c, and GluR4 each detected proteins of similar size, ranging from 102 to $108 \mathrm{kDa}$, on immunoblots of total homogenates prepared from dissected rat and monkey basal forebrains (Fig. 1). Cross-reacting proteins of other sizes were not detected with any of the antibodies, and immunodetection was abolished when antibodies were preadsorbed with synthetic peptide $(50 \mu \mathrm{g} / \mathrm{ml})$ to which they were raised (data not shown).

Using immunocytochemistry, differential localizations of GluR immunoreactivity were first revealed within neurons of the rodent basal forebrain. In rat, GluR 1 was enriched within the cell bodies and dendrites of numerous large, isodendritic neurons in the medial septal nucleus, diagonal band nucleus, magnocellular preoptic nucleus, and nucleus basalis of Meynert (NBM) (Fig. 2). Cellular and subcellular localizations were confirmed by electron microscopic analyses of Vibratome sections processed using preembedding immunocytochemistry (Fig. 3). GluR 1-positive cells had intracytoplasmic aggregates of receptor immunoreactivity within perikarya and dendrites (Figs. $2 G$, $3 A, B)$. In addition, virtually all GluR 1 -expressing neurons in the BFMC of rat had large, ellipsoid nuclei with one or several 

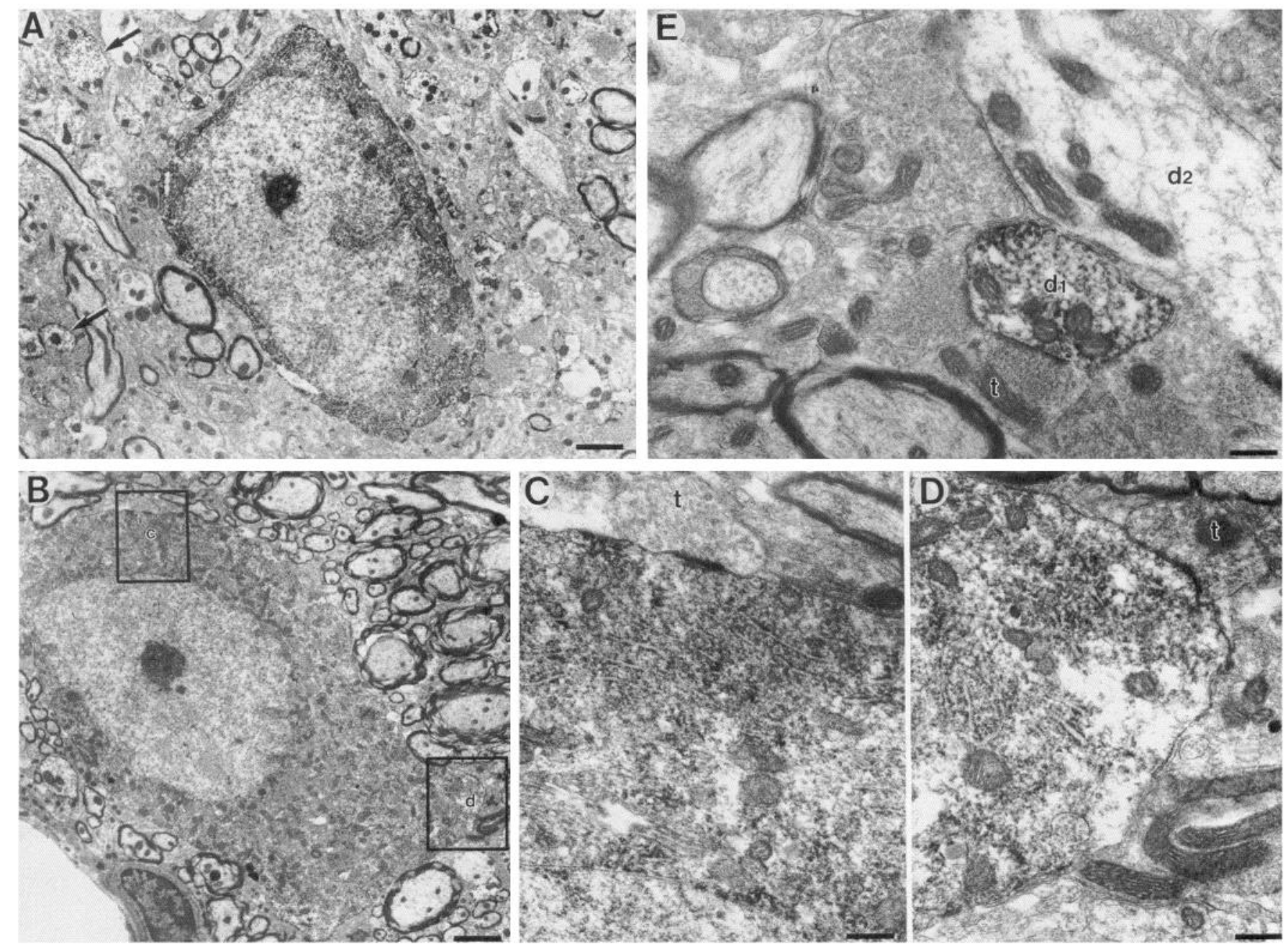

Figure 3. Ultrastructural localization of GluR1 in neurons of the magnocellular preoptic nucleus in rat. $A$ and $B$, The cytoplasm of GluR 1-positive neurons is enriched in immunoreactivity. Nuclei of these neuronal cell bodies have one or several indentations of the nuclear membrane. Within the neuropil, many dendritic profiles (arrows in $A$ ) are immunoreactive. Boxed areas in $B$ are shown at higher magnification in $C$ and $D$. Scale bars: $A, 0.9 \mu \mathrm{m} ; B, 1.1 \mu \mathrm{m}$. $C$ and $D$, Higher magnification of boxes in $B$. GluR1-immunoreactive neurons in the BFMC are contacted by unlabeled axonal terminals $(t)$ that form axosomatic synapses. Scale bars, $0.4 \mu \mathrm{m}$. $E$, Within the neuropil surrounding magnocellular neurons in the basal forebrain, GluR 1-positive aspiny dendrites $(d l)$ are contacted by axonal terminals $(t)$ that form asymmetrical synapses. Nonimmunoreactive dendrites $(d 2)$ are also visualized. Scale bar, $0.4 \mu \mathrm{m}$.

invaginations of the nuclear membrane (Fig. $3 A, B$ ). Nonimmunoreactive presynaptic axonal terminals with round, clear vesicles established axosomatic and axodendritic synapses with GluR1-positive cells (Fig. $3 C-E$ ). Within the neuropil of the BFMC, many aspiny dendritic profiles were enriched in GluR 1 (Fig. 3E).

The cellular localizations of other AMPA receptor subunits in the BFMC of rat were examined as well (Fig. 4). Relative to GluR 1 , considerably fewer magnocellular neurons showed GluR2/3/4c immunoreactivity (Fig. $4 A, B$ ). GluR4 was less abundant than either GluR1 or GluR2/3/4c; however, subsets of large GluR4-immunoreactive neurons were present within the magnocellular preoptic nucleus (Fig. 4C), NBM (Fig. 4D), and rostral ventral pallidum (Fig. 5). Many nonmagnocellular neuronal populations within the basal forebrain that are anatomically contiguous with the BFMC (e.g., nucleus accumbens, olfactory tubercle, fundus striati, sublenticular division of the bed nucleus, lateral hypothalamus, and amygdala) showed high levels of both GluR 1 and GluR2/3/4c immunoreactivities, but, within these regions, the abundance of GluR 4 immunoreactivity was low (Figs. 4, 5).

To establish whether any differences are present in the distributions of AMPA receptors in the brains of rodents and primates, the cellular localizations of AMPA receptor subunits were also identified in the BFMC of monkey (Figs. 6-8). As in rat, GluR1 was enriched within neurons in the diagonal band nuclei, magnocellular preoptic nucleus, and NBM. Control sections showed no staining for GluR1 (Fig. 6B). Within these regions, levels of GluR2/3/4c and GluR 4 were much lower (Fig. $6 C)$. However, GluR $2 / 3 / 4 \mathrm{c}$ was present in numerous neurons within several nuclei of the amygdala (Fig. $6 \mathrm{C}$ ). Because GluR 1 was the predominant AMPA receptor subunit expressed by magnocellular neurons within the basal forebrain of both rat and monkey, colocalization experiments were conducted to demonstrate the chemical phenotypes of these neurons.

Using double-label immunocytochemistry for GluR 1 and other neuronal markers, prominent differences between species were revealed. In the BFMC of rat, GluR 1 and ChAT immunoreac- 


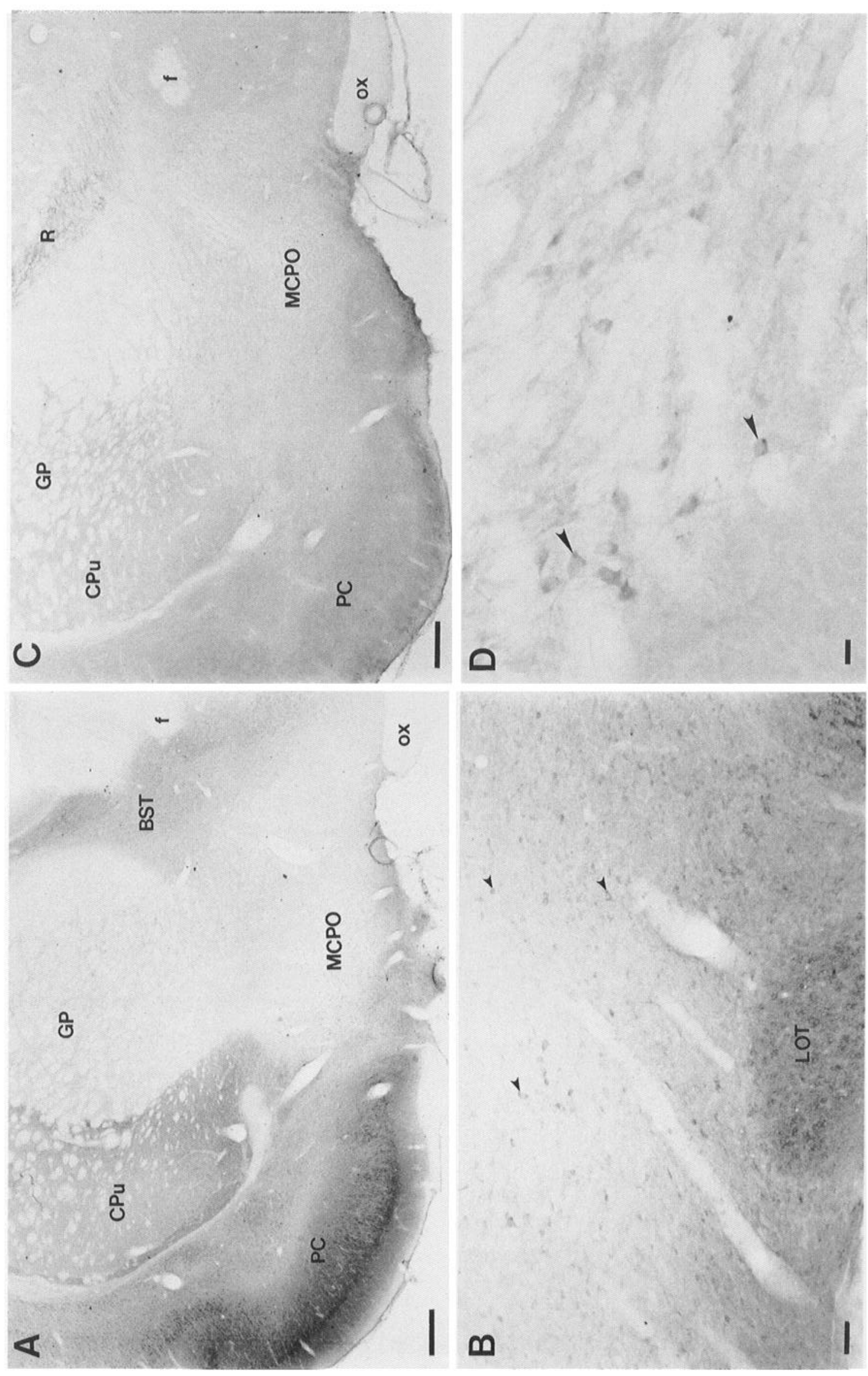

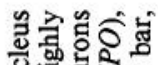

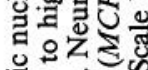
弪过 웡 때교 을 灵诺 . 군 解

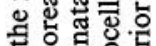

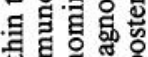

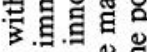

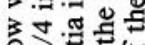
om

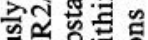

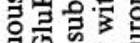

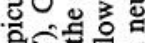
옹. ‥

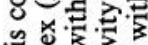
능 政 o 응 영 है

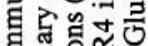
의 远 लव

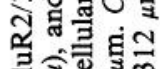
0 行 T.

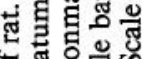
은 白

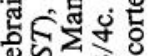
o 중 ส․ำ ฮ 드. f 0

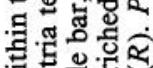
的就 $\checkmark$ 政 娄 万人 7 궁혀 न 0 굴 和苨 ले तิ

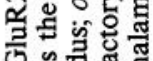

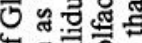

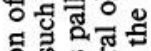
के

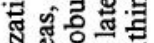
절 을

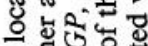
훙 3. U문.

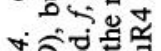

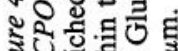
은 

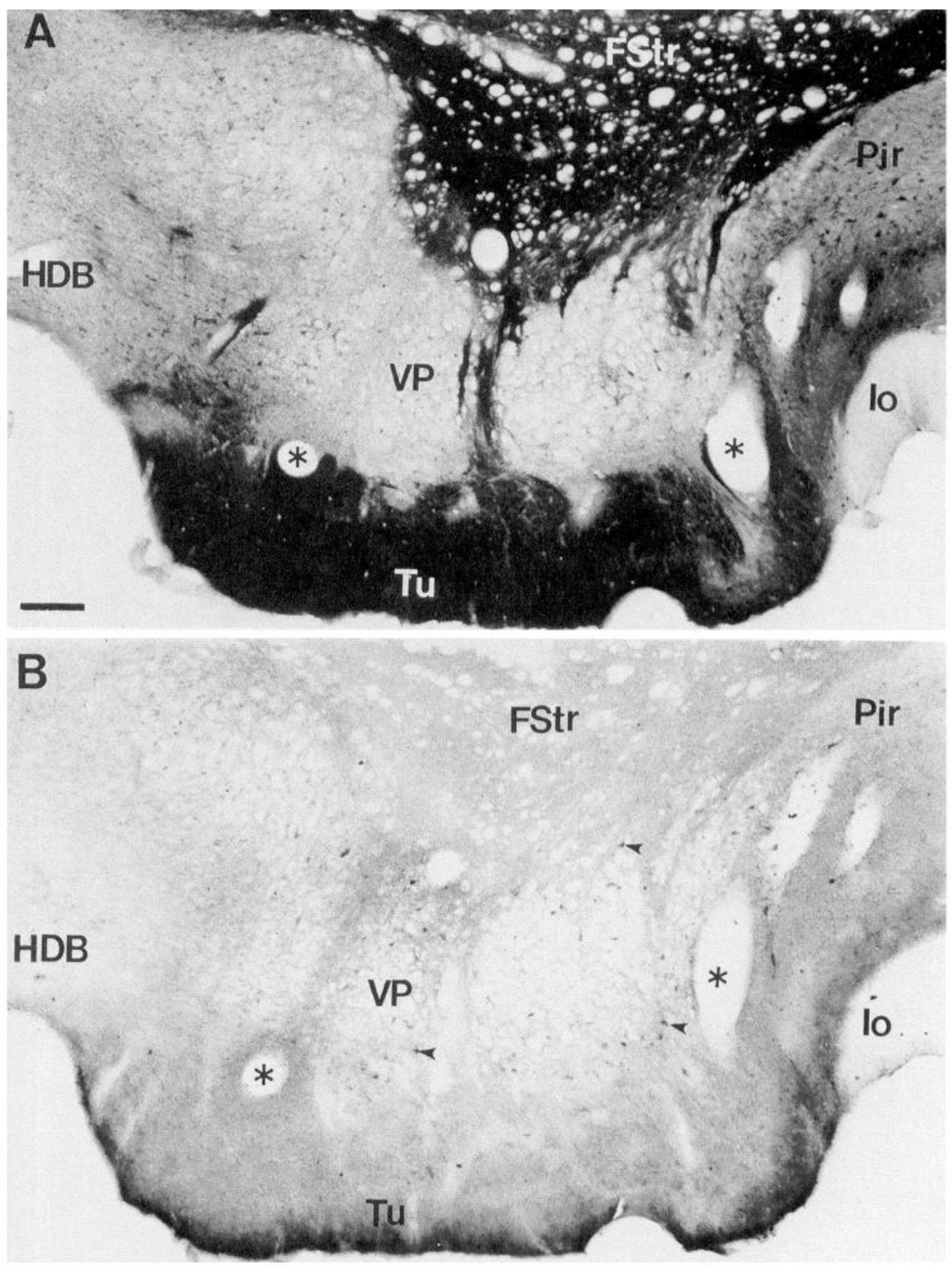

Figure 5. Localization of GluR1 and GluR4 within rostroventral striatopallidal regions. Adjacent coronal sections through the olfactory tubercle and ventral pallidum show the differential distribution of GluR $1(A)$ and GluR4 $(B$, $C)$ immunoreactivities. Asterisks (*) indicate common blood vessels. A subset of large neurons (arrowheads in $B$ and $C$ ) within the rostral ventral pallidum is selectively immunoreactive for GluR4. FStr, fundus striati; $H D B$, nucleus of the horizontal limb of the diagonal band; $l o$, lateral olfactory tract; Pir, piriform cortex; Tu, olfactory tubercle; $V P$, ventral pallidum. Scale bars: $A$ and $B, 173 \mu \mathrm{m} ; C, 19 \mu \mathrm{m}$.

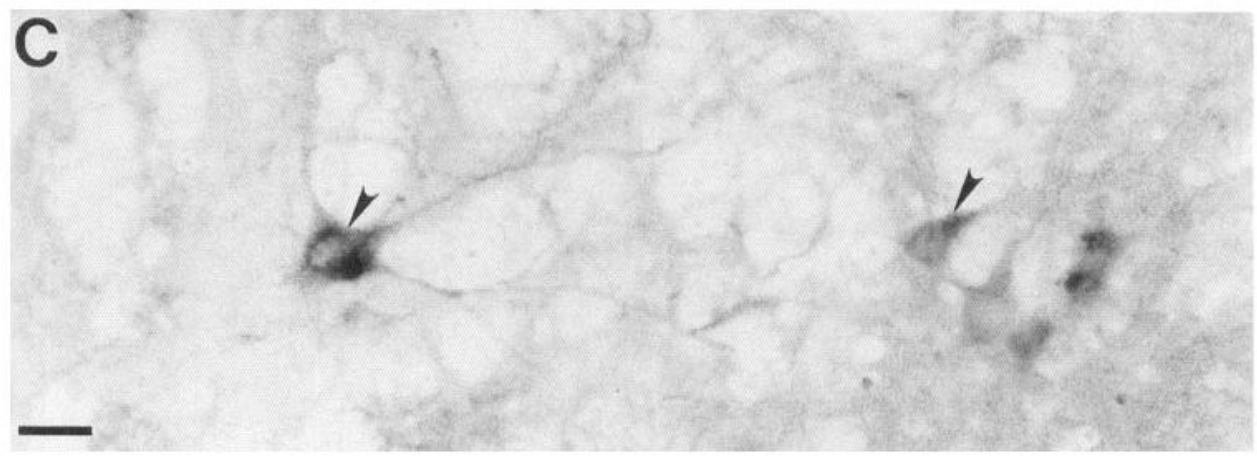

tivities were present in distinct populations of neurons (Fig. 9A$C)$. ChAT- and GluR1-positive cells were intermingled extensively (Fig. 10). In contrast, combined GluR1-ChAT preparations of monkey brains showed that nearly all ChAT neurons within the BFMC were also GluR1 positive (Fig. 9E). This pattern of colocalization within the BFMC of monkey was specific for these cholinergic neurons because large ChAT-positive neurons within the striatum of monkeys did not express GluR1 

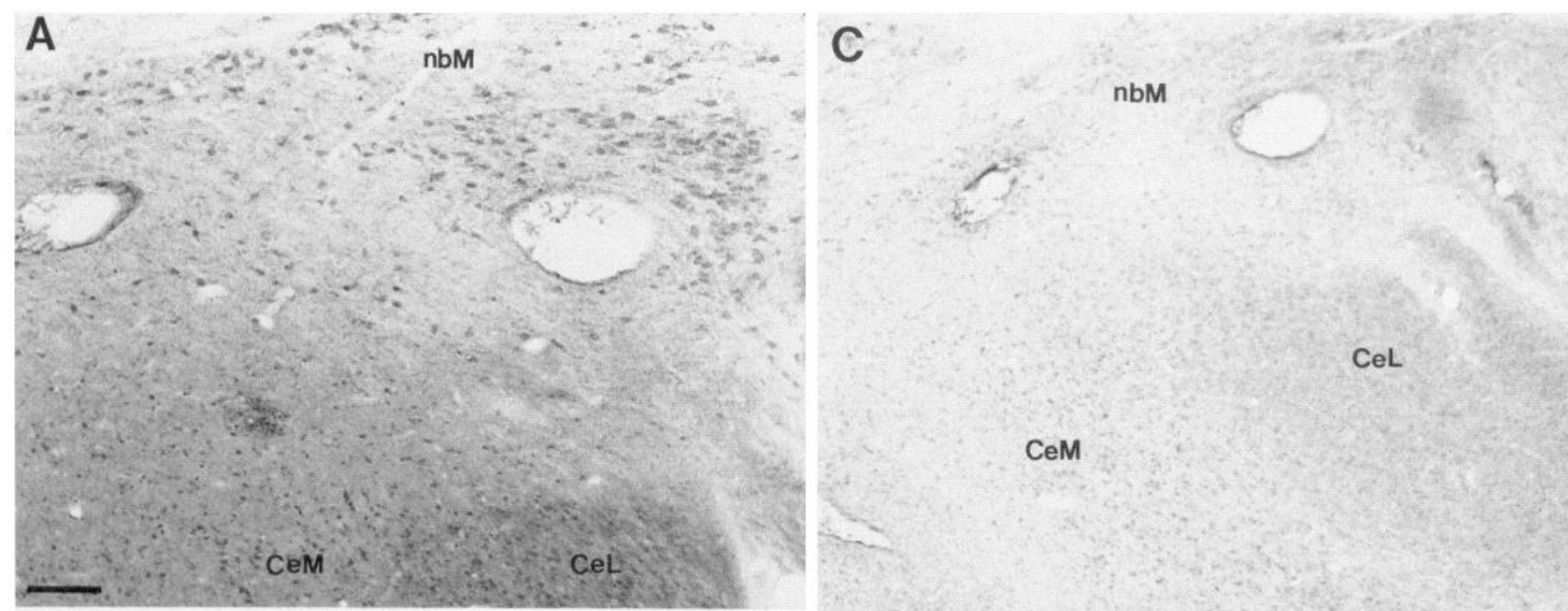

B
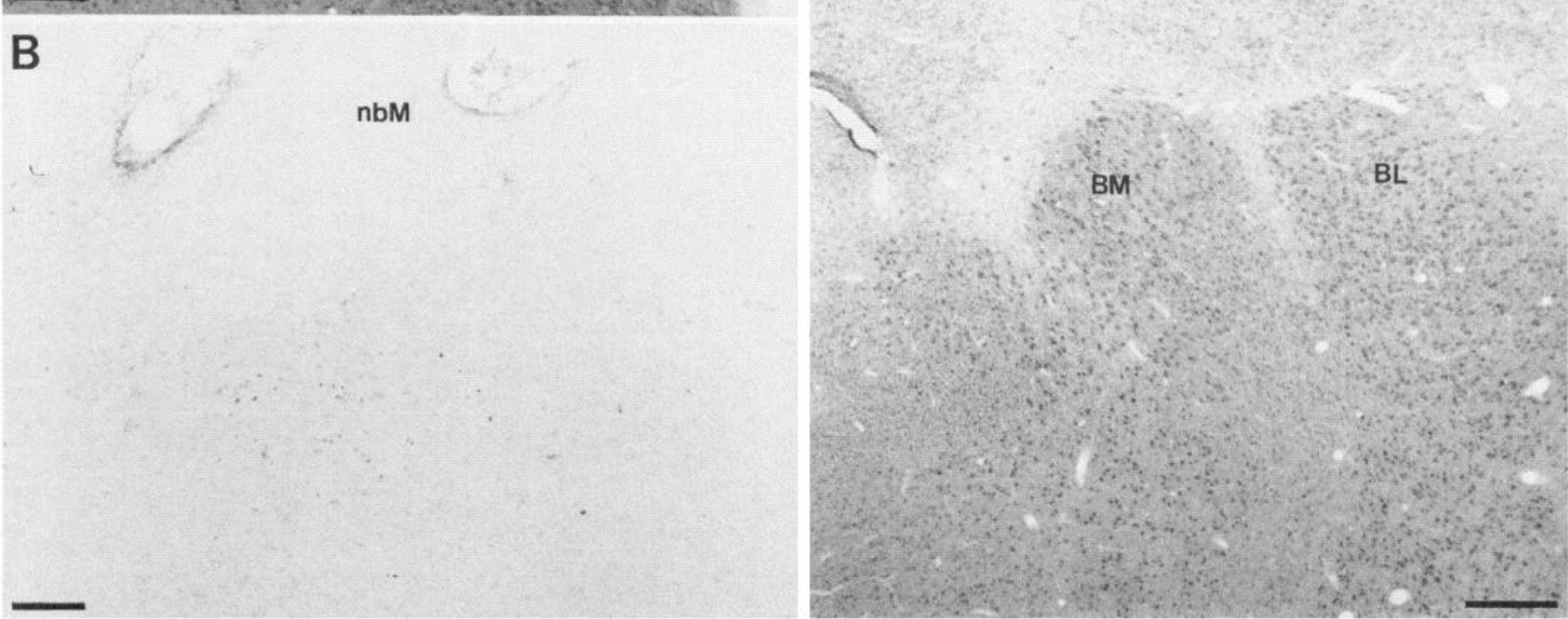

Figure 6. Differential distributions of GluR1 and GluR2/3/4c and preadsorption control for GluR1 in rhesus monkey basal forebrain. $A$, The NBM $(n b M)$ contains numerous GluR1-immunoreactive magnocellular neurons. The lateral $(\mathrm{CeL})$ and medial $(\mathrm{CeM})$ divisions of the central nucleus of the amygdala are also enriched in GluR1. Scale bar, $182 \mu \mathrm{m}$. B. Preadsorption of GluR 1 antibody with a synthetic peptide corresponding to the C-terminus of the GluR1 polypeptide abolishes all immunoreactivity within the NBM and the amygdala. Black dots in the center of the photograph represent mineral deposits or pigmentation and not immunoreactivity. Scale bar, $182 \mu \mathrm{m}$. $C$, The NBM contains few, if any, GluR2/ $3 / 4 \mathrm{c}$-immunoreactive magnocellular neurons. Lateral and medial divisions of the central nucleus of the amygdala show moderate levels of GluR2/ $3 / 4 \mathrm{c}$ immunoreactivity, whereas basolateral $(B L)$ and basomedial $(B M)$ amgydalar nuclei are enriched in GluR2/3/4c-immunoreactive neurons. Scale bar, $403 \mu \mathrm{m}$.

(Fig. $9 F$ ). In GluR1/calbindin-D28 preparations, very few large isodendritic GluR 1-containing neurons within the BFMC of rat showed calbindin-D28 immunoreactiviity, but GluR1 colocalized within the majority of calbindin-immunoreactive neurons in the BFMC of monkey (data not shown). In sections double labeled for GluR1 and markers for GABAergic neurons, the majority of GABA-, GAD-, and parvalbumin-positive neurons within the BFMC of rat, but not monkey, expressed GluR1 (Fig. $9 D)$. However, not all GluR1-immunoreactive neurons in the basal forebrain of rat were GABAergic, because many mediumsized to large multipolar and fusiform neurons immunoreactive for GluR1 were not immunoreactive for GABA, GAD, or ChAT. The transmitter phenotype of these neurons is still unclear.

\section{Discussion}

This study demonstrates that neurons within the BFMC of rat and monkey express the AMPA subtype of ionotropic GluR and that these cells express the major subunits of the AMPA receptor differentially. By immunocytochemistry, GluR 1 is the major AMPA receptor subunit expressed in cell bodies and aspiny dendrites of neurons within the BFMC in both species. Immunoblot analysis shows that both GluR 1 and GluR2/3/4c are enriched similarly in homogenates of dissected basal forebrain; the abundance of GluR4 is low within this region of the brain. On immunoblots, GluR antibodies detect GluR proteins from a variety of different neuronal populations within the basal forebrain. The majority of GluR1 and, particularly, GluR2/3/ $4 \mathrm{c}$ immunoreactivities detected by immunoblotting is likely to be derived from nonmagnocellular and, less prominently, magnocellular neuronal compartments within the basal forebrain that show intense positive staining as revealed by immunocytochemistry. Thus, because of the cellular heterogeneity of the basal forebrain, an immunocytochemical evaluation of the distributions of GluR was crucial for the precise identification of neurons that specifically express these receptor proteins.

Most large cells within the BFMC are either cholinergic (Me- 

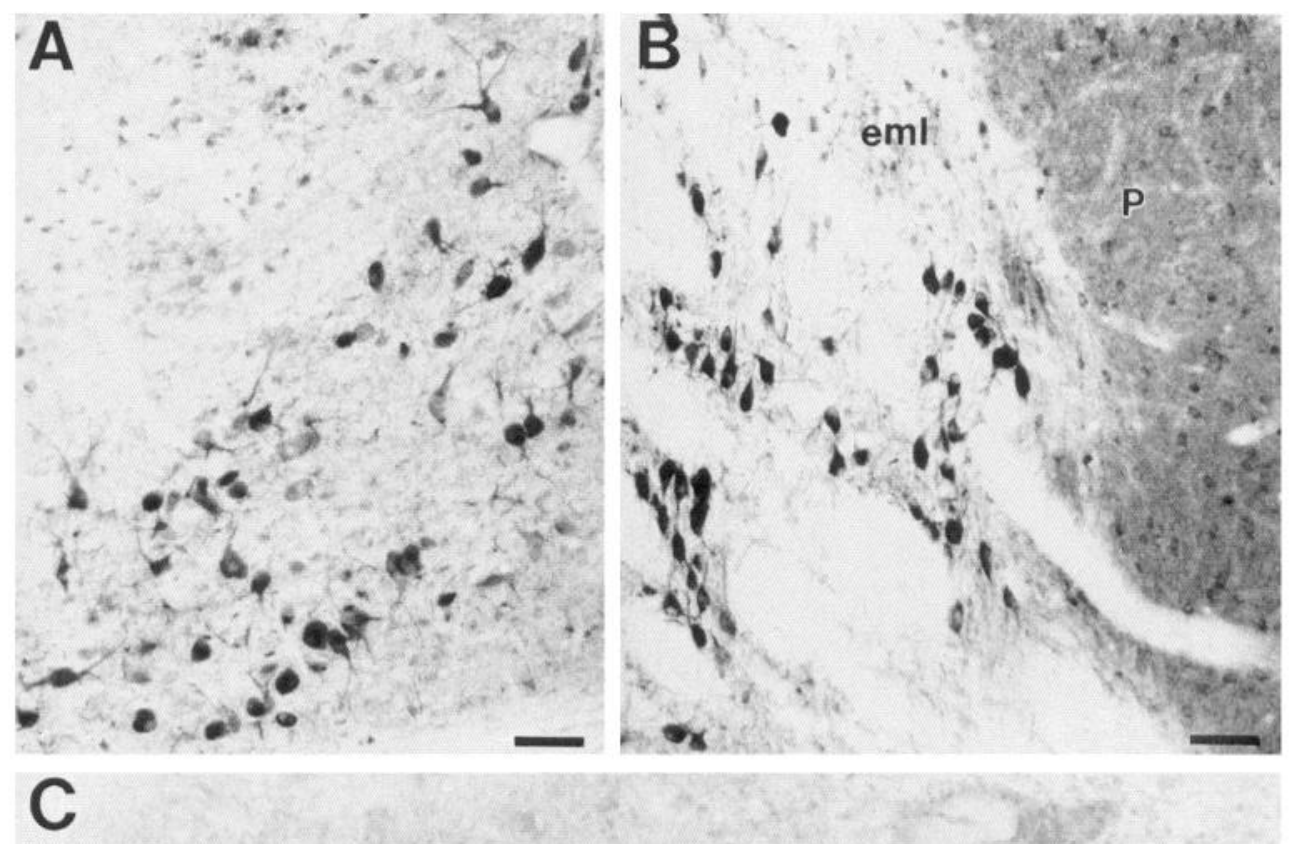

Figure 7. Cellular localization of GluR 1 within the nucleus of the diagonal band and the NBM in primates. $A$, GluR 1-immunoreactive neurons are present within the nucleus of the horizontal limb of the diagonal band of Bro$\mathrm{ca}$ in a lion-tailed macaque. Scale bar, $72 \mu \mathrm{m}$. B, Many GluR1-positive magnocellular neurons are found within the posterior NBM in rhesus monkey. eml, external medullary lamina; $P$, putamen. Scale bar, $56 \mu \mathrm{m}$. $C$, In plastic sections ( $1 \mu \mathrm{m}$ thick) of the NBM in macaque, GluR 1 is enriched within the cytoplasm of magnocellular neurons. Scale bar, $10 \mu \mathrm{m}$.

sulam et al., 1983a,b, 1984) or GABAergic (Köhler et al., 1984; Brashear et al., 1986; Walker et al., 1989) neurons. In this region, $\mathrm{GAD}$, the enzyme that synthesizes GABA, does not colocalize with ChAT in individual neurons (Brashear et al., 1986) but does colocalize with parvalbumin, a calcium-binding protein that marks subsets of GABAergic neurons within the BFMC of rat (Kiss et al., 1990). In contrast, calbindin-D28, another calcium-binding protein, is a marker for cholinergic neurons in the BFMC in primates (Celio and Norman, 1985; Schatz et al., 1990; Chang and Kuo, 1991).

The present study of the BFMC shows that GABAergic neurons of rat express GluR1, whereas cholinergic neurons of primate express GluR 1 . These neurons were characterized by their transmitter-synthesizing enzymes and ultrastructural morphology. Because other major subunits of the AMPA receptor are expressed in low abundance in this population of neurons, potential species differences in these subunits were not evaluated. It is unlikely that these observed species differences in the cellular localization of GluR 1 are caused by methodological considerations. Although these antibodies were generated against peptides derived from the predicted polypeptide sequences encoded by the rat AMPA GluR genes, the human homolog of the GluR1 gene (i.e., GluHI) is nearly identical $(97 \%$ amino acid identity) to the rat GluR1 gene (Puckett et al., 1991). Moreover, these antibodies detect bands of protein with similar molecular masses in rat, monkey, and human brains (Fig. 1) (Blackstone et al., 1992a,b). It is possible that these species differences in the cellular localization of AMPA receptors within the BFMC represent a phylogenetic transformation in the mechanisms by which glutamatergic synapses influence information transfer within the basal forebrain. In the course of evolution, the BFMC and, in particular, the NBM have undergone prominent phylogenetic changes that seem to parallel the development of neocortex (Gorry, 1963). In rodents, insectivores, and carnivores, the NBM is incompletely segregated from contiguous basal forebrain regions (Gorry, 1963; Parent, 1986). Thus, glutamatergic mechanisms, as well as molecular subtypes of GluR expressed by subsets of neurons, may have been modified commensurately with the development of the forebrain. The expression of AMPA receptors in cholinergic neurons of the BFMC in primates may reflect a direct, excitatory, glutamatergic feedback from neocortex or limbic regions.

Inputs to the BFMC originate mainly from limbic and paralimbic cortical regions, amygdala, thalamus, and brainstem; 
A

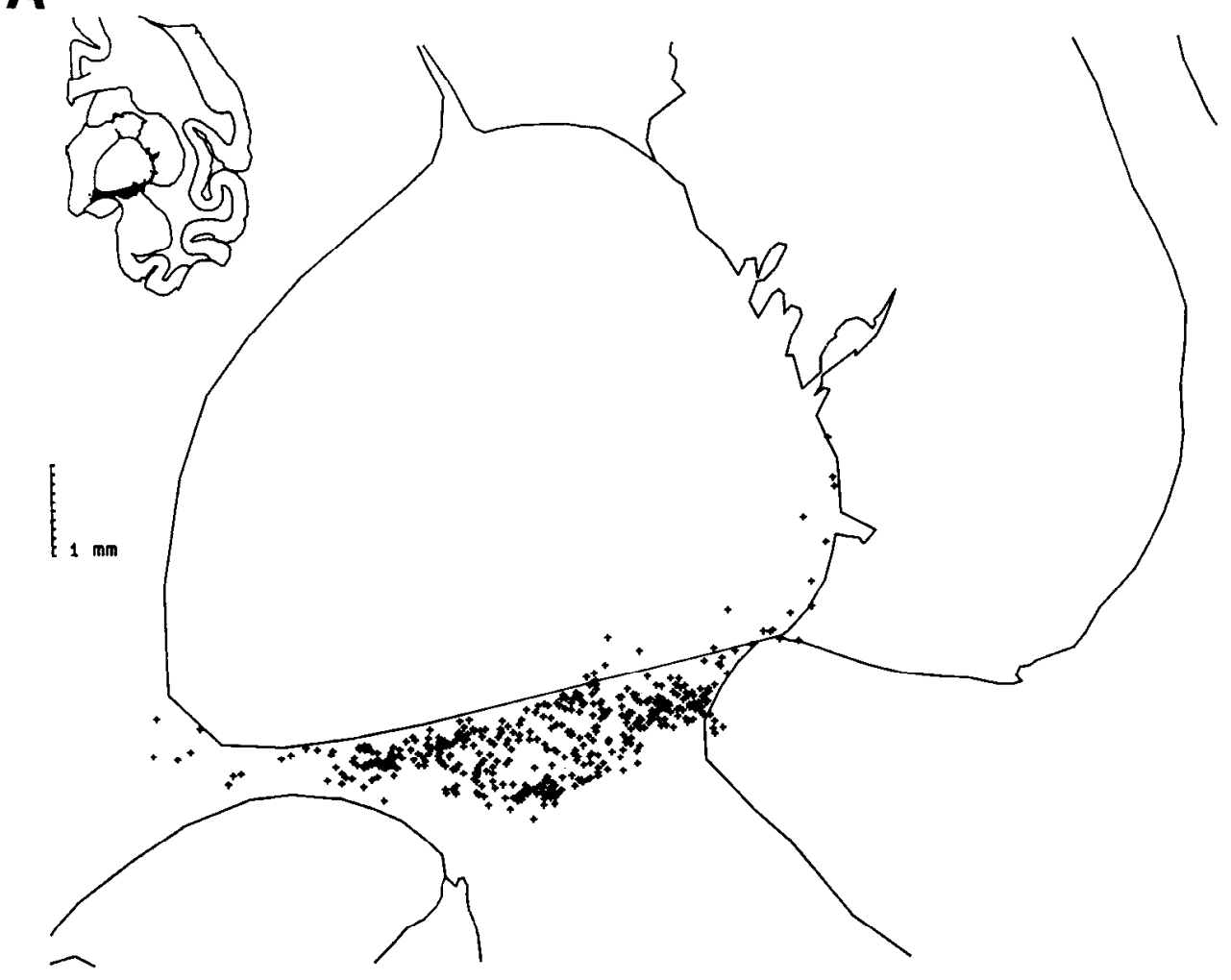

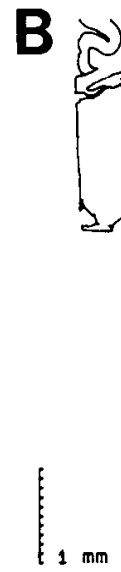

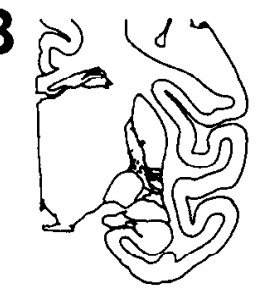

...

many of these afferents may use glutamate or aspartate as their neurotransmitter (Zaczek et al., 1979; Walaas and Fonnum, 1980; Mesulam and Mufson, 1984; Woolfe et al., 1984; Carnes et al., 1990; Jaskiw et al., 1991). The presence of cholinergic or GABAergic BFMC neurons that are enriched in AMPA receptor
Figure 8. Topographic distributions of GluR 1-immunoreactive neurons in the basal forebrain of primate: representative maps showing the distributions of GluR 1-positive neurons in the anterior $(A)$ and posterior $(B)$ NBM of the rhesus monkey. Insets (upper left) show the level of the section. Each symbol $(+$ or $x$ ) represents one neuronal cell body. Scale is at left. subunits indicates that these cell bodies and dendrites express glutamate-gated ion channels and are regulated by glutamatergic synapses. In rat, our ultrastructural demonstration that GluR 1positive neurons establish axosomatic and axodendritic synapses with terminals containing round, clear vesicles is consis- 


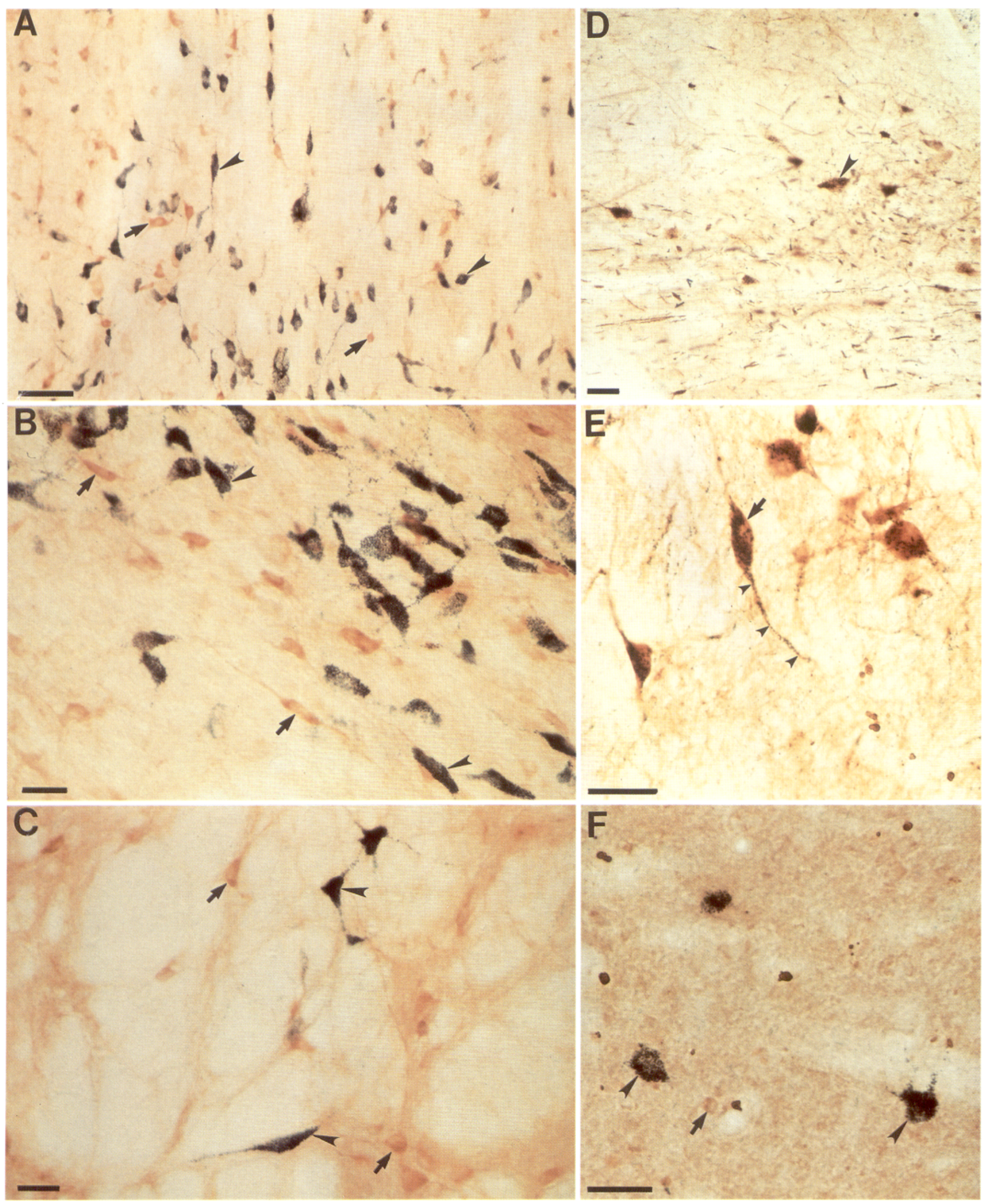




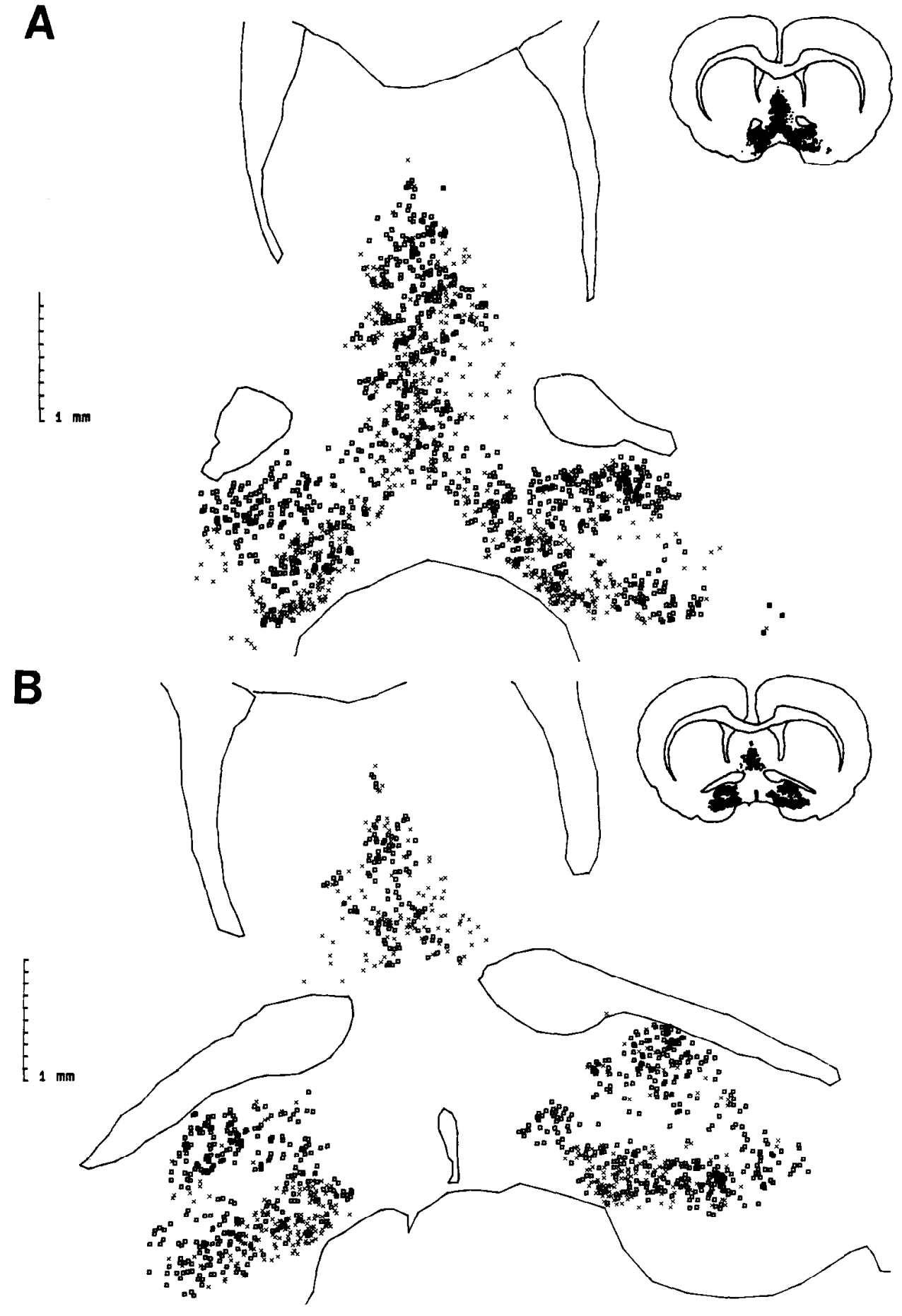

Figure 10. Topographic distribution of AMPA receptor-expressing neurons and cholinergic neurons within the basal forebrain of rat. Plots from representative double-labeled sections showing that GluR1-immunoreactive neurons (squares) and ChAT-immunoreactive neurons $(x)$ are different populations of cells within the rat basal forebrain. $A$ is more rostral than $B$. Insets (upper right) show the level of the section. Each symbol (square or $x$ ) represents one neuronal cell body. Scale is at left.

Figure 9. Colocalization of GluR1 with other neuronal markers in the BFMC of rat and monkey. $A-C$, Within the medial septal nucleus $(A)$, nucleus of the diagonal band $(B)$, and NBM $(C)$ of rat, GluR 1 and ChAT immunoreactivities are segregated within distinct subsets of neurons. Arrowheads identify representative ChAT-positive neurons labeled with BDHC(blue-green, granular reaction product). Arrows identify representative GluR 1-immunoreactive neurons labeled with diaminobenzidine (brown reaction product). Scale bars: $A, 62 \mu \mathrm{m} ; B, 25 \mu \mathrm{m} ; C, 20 \mu \mathrm{m}$. $D, \mathrm{GluR} 1$ and parvalbumin immunoreactivities colocalize within subsets of neurons (arrowhead) within the BFMC of rat. Scale bar, $36 \mu \mathrm{m}$. $E$, Within the NBM (as well as other BFMC regions) of nonhuman primate, GluR1 colocalizes within virtually all cholinergic neurons (arrow). GluR1 was visualized with diaminobenzidine; ChAT was visualized with benzine dihydrochloride. Long, smooth dendrites are found to be double labeled (arrowheads). Scale bar, $38 \mu \mathrm{m}$. $F$, Within the same section of monkey brain seen in $E$, GluR I does not colocalize with magnocellular cholinergic neurons within the striatum. GluR 1-positive neurons (arrow) and ChAT-immunoreactive neurons (arrowheads) are distinct subsets of cells within this region. Scale bar, $40 \mu \mathrm{m}$. 
tent with this idea. In in vitro slice preparations of the rodent medial septum-diagonal band complex, cholinergic and noncholinergic neurons (presumably GABAergic neurons) differ in action potential parameters, spike afterpotentials, and currentvoltage relationships (Markram and Segal, 1990). Moreover, in culture, cholinergic basal forebrain neurons (but not noncholinergic neurons) have broad action potentials with a $\mathrm{Ca}^{2+}$ component (Segal, 1986; Griffith, 1988). The finding that cholinergic and noncholinergic neurons within the BFMC have different patterns of GluR expression may explain, in part, their different excitatory electrophysiological characteristics, because these different subsets of neurons may express distinct ion channels. Moreover, cholinergic and noncholinergic BFMC neurons may express other subtypes of GluR (such as NMDA receptors, KA receptors, or phosphoinositide-linked metabotropic receptors), which may contribute to their differential electrophysiological properties.

The results of this study may be relevant to the functions of septohippocampal projections, because this circuit is an important modulator of long-term potentiation (LTP) of synaptic efficacy within hippocampus. LTP can be induced preferentially in maximally depolarized neurons (Larson et al., 1986; Pavlides et al., 1988), and EPSP-spike (E-S) potentiation, a form of LTP produced by tetanic stimulation of the glutamatergic perforant path, is enhanced in dentate gyrus by pairing septal and perforant path trains (Robinson, 1986). In this model, coactivation of the excitatory perforant path and septal GABAergic and/or cholinergic projections to hippocampus would maximize hippocampal responsiveness. The functional interpretations of our results suggest that glutamate-mediated activation of AMPA recceptor-expressing, GABAergic, hippocampopetal neurons within the septum would reduce postsynaptic inhibition and, indirectly, augment excitability of granule and pyramidal neurons in hippocampus. Support for this idea is found in studies showing that GABAergic inhibitory projections from the medial septum synapse on inhibitory interneurons in hippocampus (Freund and Antal, 1988; Gulyás et al., 1991) and that picrotoxin, a GABA receptor antagonist, blocks tetanus-induced E-S potentiation in rodent hippocampus (Fantie and Goddard, 1982; Bilkey and Goddard, 1985). In contrast, the excitation of AMPA receptor-expressing, cholinergic, hippocampopetal neurons within the septum may directly increase the intrinsic postsynaptic excitability of the hippocampus. Support for this idea is derived from observations showing that cholinergic neurons within the septum innervate all major cell groups in the hippocampal formation (Frotscher, 1989) and ACh excites hippocampal pyramidal cells (Kelly et al., 1979; Krnjević et al., 1982). AMPA receptor-activated medial septal efferents may, thus, modulate the balance of excitation and inhibition within hippocampus and, perhaps, facilitate perforant path-driven, NMDA receptor-mediated postsynaptic plasticity within hippocampal neurons. Wc conclude that the synaptic regulation of neural networks designed to modulate hippocampal function, including glutamatergic inputs to septal cholinergic and GABAergic neurons that project to hippocampus, differ in rodents and primates. However, despite anatomical differences, the electrophysiological and functional outcomes of activation of these neural systems may be similar in rodents and primates.

The physiological activity of cholinergic neurons within the BFMC is believed to be important for mechanisms of memory, cognition (Bartus et al., 1986; Olton and Wenk, 1987), and reinforcement (Wilson and Rolls, 1990). To study the roles of the basal forebrain in tests for learning and memory, excitotoxic, axon-sparing lesions are made with excitatory amino acid analogs that destroy neurons in the basal forebrain (Dunnett et al., 1991; Fibiger, 1991). Ibotenate, KA, and NMDA lesions of the basal forebrain cause robust deficits in performance on a variety of tasks for discrimination, learning, and memory, but these toxins damage a variety of different neuronal populations within the basal forebrain (Dunnett et al., 1991; Page et al., 1991). In contrast, AMPA-induced lesions of the rodent basal forebrain cause only marginal deficits in behavioral tasks, but AMPA is purported to be more selective for destroying cholinergic neurons while sparing pallidal and other noncholinergic neurons (Page et al., 1991). However, in these paradigms, excitotoxic effects on GABAergic neurons within the basal forebrain have not been ascertained (Dunnett et al., 1991; Page et al., 1991). Our present and previous results (Blackstone et al., 1992b; Price et al., 1992) show that AMPA receptors are expressed in several nonmagnocellular and magnocellular neuronal populations within the basal forebrain, including the nucleus accumbens, ventral pallidum, and bed nucleus-amygdala continuum, as well as in GABAergic neurons of rat and cholinergic neurons in monkey. The infusion of pharmacological dosages of AMPA is unlikely to discriminate between populations of transmitterand connectivity-specific neurons within the basal forebrain. In addition, injury of cholinergic neurons in the BFMC may result secondarily from a persistent reduction of GABAergic synaptic inhibition ensuing from primary excitotoxic destruction of GABAergic neurons that innervate cholinergic neurons (Leranth and Frotscher, 1989; Zaborszky et al., 1986). In the basal forebrain of rat, our findings that noncholinergic GABAergic neurons (but not magnocellular cholinergic neurons) express AMPA receptors would support this idea. Thus, the present results emphasize the need to interpret the functional consequences of excitotoxic lesions in the basal forebrain in relation to the cellular heterogeneity, microcircuitry, and receptor-mediated regulation of this region as well as the species differences in the anatomical and, perhaps, synaptic organization of the BFMC.

Our findings may provide some insight into human neurological disorders where dysfunction of the BFMC has been implicated. Aged individuals and patients with Alzheimer's disease manifest learning and memory deficits that result, in part, from loss or atrophy of magnocellular basal forebrain cholinergic neurons projecting to hippocampus and neocortex (Bowen et al., 1976; Davies and Maloney, 1976; Whitehouse et al., 1982; Candy et al., 1983; Price et al., 1985). Endogenous excitotoxins that act as GluR agonists may participate in the neuronal injury and death that occurs in chronic neurodegenerative diseases, including Alzheimer's disease (Choi, 1988; Greenamyre and Young, 1989; Olney, 1991). The abnormal activation of subtypes of GluR and the subsequent elevation of intracellular $\mathrm{Ca}^{2+}$ levels and disruption of cellular energy metabolism are thought to be primary mechanisms of excitotoxic cell injury (Choi, 1988; Novelli et al., 1988; Olney, 1991; Beal, 1992). This study provides relevant results in this regard by demonstrating the expression of AMPA receptors in cholinergic neurons of the BFMC in nonhuman primates. Moreover, this study shows that GluR1 is the predominant subunit expressed by these neurons. GluR4 and GluR2, GluR3, or GluR4c are also present in this region, but at levels lower than GluR 1. In Xenopus oocytes, AMPA receptor channels, formed by certain combinations of subunits, are permeable to $\mathrm{Ca}^{2+}$ (Hollmann et al., 1991). For example, inward $\mathrm{Ca}^{2+}$ currents are seen with channels formed by GluR1, 
GluR3, and GluR 1 plus GluR3, but assemblies of GluR 1 plus GluR2 and GluR3 plus GluR2 are not permeable to $\mathrm{Ca}^{2+}$ (Hollmann et al., 1991). Site-directed mutagenesis experiments show that a single amino acid change (glutamine to arginine) at position 586 in the putative second transmembrane segment of GluR2 is responsible for subunit-specific current-voltage relations and $\mathrm{Ca}^{2+}$ permeability (Verdoorn et al., 1991). It is interesting that, among GluR 1-GluR4, the dominant AMPA receptor subunit in cholinergic neurons of the BFMC of primates is GluR 1 [a subunit that, when expressed alone, forms functional channels permeable to $\mathrm{Ca}^{2}$ (Hollmann et al., 1991)]. Thus, changes in the subunit composition of ionotropic GluR or mutations in the genes that encode these receptor subunits could render cholinergic neurons within the BFMC selectively vulnerable to excitotoxic injury in age-associated neurodegenerative diseases. Future studies on the regional and cellular localization of GluR proteins in human brain are needed to clarify the status of these receptor proteins in aged individuals, subjects with Alzheimer's disease, and patients with other neurological disorders in which excitoxicity may play a role.

\section{References}

Aigner TG, Mitchell SJ, Aggleton JP, DeLong MR, Struble RG, Price DL, Wenk GL, Mishkin M (1987) Effects of scopolamine and physostigmine on recognition memory in monkeys with ibotenic acidinduced lesions of the nucleus basalis of Meynert. Psychopharmacology 92:292-300.

Bartus RT, Dean RL, Fisher SK (1986) Cholinergic treatment for agerelated memory disturbances. In: Treatment development strategies for Alzheimer's disease (Crook T, Bartus RT, Ferris S, Gershon S, eds), pp 421-450. Madison, CT: Powley.

Beal MF (1992) Does impairment of energy metabolism result in excitotoxic neuronal death in neurodegenerative illnesses? Ann Neurol 31:119-130.

Berod A, Hartman BK, Pujol JF (1981) Importance of fixation in immunohistochemistry: use of formaldehyde solutions at variable $\mathrm{pH}$ for the localization of tyrosine hydroxylase. J Histochem Cytochem 29:844-850.

Bettler B, Boulter J, Hermans-Borgmeyer I, O'Shea-Greenfield A, Deneris ES, Moll C, Borgmeyer U, Hollmann M, Heinemann S (1990) Cloning of a novel glutamate receptor subunit, GluR5: expression in the nervous system during development. Neuron 5:583-595.

Bettler B, Egebjerg J, Sharma G, Pecht G, Hermans-Borgmeyer I, Moll C, Stevens CF, Heinemann S (1992) Cloning of a putative glutamate receptor: a low affinity kainite-binding subunit. Neuron 8:257-265.

Bilkey DK, Goddard GV (1985) Medial septal facilitation of hippocampal granule cell activity is mediated by inhibition of inhibitory interneurones. Brain Res 361:99-106.

Blackstone CD, Levey AI, Martin LJ, Price DL, Huganir RL (1992a) Immunological detection of glutamate receptor subtypes in human central nervous system. Ann Neurol 31:680-683.

Blackstone CD, Moss SJ, Martin LJ, Levey AI, Price DL, Huganir RL (1992b) Biochemical characterization and localization of a non- $N$ methyl-D-aspartate glutamate receptor in rat brain. J Neurochem 58: 1118-1126.

Boulter J, Hollmann M, O'Shea-Greenfield A, Hartley M, Deneris E, Maron C, Heinemann S (1990) Molecular cloning and functional expression of glutamate receptor subunit genes. Science 249:10331037.

Bowen DM, Smith CCT, White P, Davison AN (1976) Senile dementia and related abiotrophies: biochemical studies on historically evaluated human postmortem specimens. In: Aging, Vol 3, Neurobiology of aging (Terry RD, Gershon S, eds), pp 361-389. New York: Raven.

Brashear HR, Záborszky L, Heimer L (1986) Distribution of GABAergic and cholinergic neurons in the rat diagonal band. Neuroscience 17:439-451.

Candy JM, Perry RH, Perry EK, Irving D, Blessed G, Fairbairn AF, Tomlinson BE (1983) Pathological changes in the nucleus of Meynert in Alzheimer's and Parkinson's diseases. J Neurol Sci 59:277289.

Carnes KM, Fuller TA, Price JL (1990) Sources of presumptive glu- tamatergic/aspartatergic afferentes to the magnocellular basal forebrain in the rat. J Comp Neurol 302:824-852.

Celio MR, Norman AW (1985) Nucleus basalis Meynert neurons contain the vitamin D-induced calcium-binding protein (calbindin-D 28k). Anat Embryol (Berl) 173:143-148.

Chang HT, Kuo H (1991) Relationship of calbindin-D28K and cholinergic neurons in the nucleus basalis of meynert of the monkey and the rat. Brain Res 549:141-145.

Choi DW (1988) Glutamate neurotoxicity and diseases of the nervous system. Neuron 1:623-634.

Davies P, Maloney AJF (1976) Selective loss of central cholinergic neurons in Alzheimer's disease. Lancet 2:1403.

Davies SW, McBcan GJ, Roberts PJ (1984) A glutamatergic innervation of the nucleus basalis/substantia innominata. Neurosci Lett 45:105-110.

Lunnett SB, Everitt BJ, Robbins TW (1991) The basal forebraincortical cholinergic system: interpreting the functional consequences of excitotoxic lesions. Trends Neurosci 14:494-501.

Egebjerg J, Bettler B, Hermans-Borgmeyer I, Heinemann S (1991) Cloning of a cDNA for a glutamate receptor subunit activated by kainite but not AMPA. Nature 351:745-748.

Fagg GE, Foster AC (1983) Amino acid neurotransmitters and their pathways in the mammalian central nervous system. Neuroscience 9:701-719.

Fantic BD, Goddard GV (1982) Septal modulation of the population spike in the fascia dentata produced by perforant path stimulation in the rat. Brain Res 252:227-237.

Fibiger HC (1991) Cholinergic mechanisms in learning, memory and dementia: a review of recent evidence. Trends Neurosci 14:220-223.

Fibiger HC, Lehmann J (1981) Anatomical organization of some cholinergic systems in the mammalian forebrain. In: Advances in behavioral biology, Vol 25, Cholinergic mechanisms: phylogenetic aspects, central and peripheral synapses, and clinical significance (Pepeu G, Ladinsky H, eds), pp 663-672. New York: Plenum.

Fonnum F (1984) Glutamate: a neurotransmitter in mammalian brain. J Neurochem 42:1-11.

Freund TF, Antal M (1988) GABA-containing neurons in the septum control inhibitory interneurons in the hippocampus. Nature 36:170173.

Frotscher M (1989) Central cholinergic synapses: the septohippocampal system as a model. In: Central cholinergic synaptic transmission (Frotscher M, Misgeld U, eds), pp 33-41. Basel: Birkhäuser.

Fuller TA, Russchen FT, Price JL (1987) Sources of presumptive glutamergic/aspartergic afferents to the rat ventral striatopallidal region. J Comp Neurol 258:317-338.

Gallo V, Upson LM, Hayes WP, Vyklicky L Jr, Winters CA, Buonanno A (1992) Molecular cloning and developmental analysis of a new glutamate receptor subunit isoform in cerebellum. J Neurosci 12: $1010-1023$.

Gasic GP, Heinemann S (1991) Receptors coupled to ionic channels: the glutamate receptor family. Curr Opin Neurobiol 1:20-26.

Gaykema RPA, van der Kuil J, Hersh LB, Luiten GM (1991) Patterns of direct projections from the hippocampus to the medial septumdiagonal band complex: anterograde tracing with Phaseolus vulgaris leucoagglutinin combined with immunohistochemistry of choline acetyltransferase. Neuroscience 43:349-360.

Gorry JD (1963) Studies on the comparative anatomy of the ganglion basale of Meynert. Acta Anat (Basel) 55:51-104.

Greenamyre JT, Young AB (1989) Excitatory amino acids and Alzheimer's disease. Neurobiol Aging 10:593-602.

Griffith WH (1988) Membrane properties of cell types within guinea pig basal forebrain nuclei in vitro. J Neurophysiol 59:1590-1612.

Gulyás AI, Seress L, Tóth K, Acsády, Antal M, Freund TF (1991) Septal GABAergic neurons innervate inhibitory interneurons in the hippocampus of the macaque monkey. Neuroscience 41:381-390.

Halpain S, Wieczorek CM, Rainbow TC (1984) Localization of L-glutamate receptors in rat brain by quantitative autoradiography. J Neurosci 4:2247-2258.

Hepler DJ, Olton DS, Wenk GL, Coyle JT (1985) Lesions in nucleus basalis magnocellularis and medial septal area of rats produce qualitatively similar memory impairments. J Neurosci 5:866-873.

Herb A, Brunashev N, Werner P, Sakmann B, Wisden W, Seeburg PH (1992) The KA-2 subunit of excitatory amino acid receptors shows widespread expression in brain and forms ion channels with distantly related subunits. Neuron 8:775-785. 
Hollmann M, O'Shea-Greenfield A, Rogers SW, Heinemann S (1989) Cloning by functional expression of a member of the glutamate receptor family. Nature 342:643-648.

Hollmann M, Hartley M, Heinemann S (1991) $\mathrm{Ca}^{2+}$ permeability of KA-AMPA-gated glutamate receptor channels depends on subunit composition. Science 252:851-852.

Jaskiw GE, Tizabi Y, Lipska BK, Kolachana BS, Wyatt RJ, Gilad GM (1991) Evidence for a frontocortical-septal glutamatergic pathway and compensatory changes in septal glutamate uptake after cortical and fornix lesions in the rat. Brain Res 550:7-10.

Keinänen K, Wisden W, Sommer B, Werner P, Herb A, Verdoorn TA, Sakmann B, Seeburg PH (1990) A family of AMPA-selective glutamate receptors. Science 249:556-560.

Kelly JS, Dodd J, Dingledine R (1979) Acetylcholine as an excitatory and inhibitory transmitter in the mammalian central nervous system. In: Progress in brain research, Vol 49, The cholinergic synapse (Tuček S, ed), pp 253-266. Amsterdam: Elsevier.

Kiss J, Patel AJ, Baimbridge KG, Freund TF (1990) Topographical localization of neurons containing parvalbumin and choline acetyltransferase in the medial septum-diagonal band region of the rat. Neuroscience 36:61-72.

Köhler C, Chan-Palay V, Wu J-Y (1984) Septal neurons containing glutamic acid decarboxylase immunoreactivity project to the hippocampal region in the rat brain. Anat Embryol (Berl) 169:41-44.

Krnjević K, Ropert N (1982) Electrophysiological and pharmacological characteristics of facilitation of hippocampal population spikes by stimulation of the medial septum. Neuroscience 7:2165-2183.

Krnjević K, Reinhardt W, Ropert N (1982) Choline as an acetylcholine agonist in the mammalian neocortex and hippocampus. In: Aging, Vol 19, Alzheimer's disease: a Report of progress in research (Corkin S, Davis KL, Growdon JH, Usdin E, Wurtman RJ, eds), pp 331344. New York: Raven.

Lakos S, Basbaum AI (1986) Benzidine dihydrochloride as a chromogen for single- and double-label light and electron microscopic immunocytochemical studies. J Histochem Cytochem 34:1047-1056.

Larson J, Wong D, Lynch G (1986) Patterned stimulation at the theta frequency is optimal for the induction of hippocampal long-term potentiation. Brain Res 368:347-350.

Lemann W, Saper CB (1985) Evidence for a cortical projection to the magnocellular basal nucleus in the rat: an electron microscopic axonal transport study. Brain Res 334:339-343.

Leranth C, Frotscher M (1989) Organization of the septal region in the rat brain: cholinergic-GABAergic interconnections and the termination of hippocampo-septal fibers. J Comp Neurol 289:304-314.

Levey AI, Bolam JP, Rye DB, Hallanger AE, Demuth RM, Mesulam M-M, Wainer BH (1986) A light and electron microscopic procedure for sequential double antigen localization using diaminobenzidine and benzidine dihydrochloride. J Histochem Cytochem 34:14491457.

Markram H, Segal M (1990) Electrophysiological characteristics of cholinergic and non-cholinergic neurons in the rat medial septumdiagonal band complex. Brain Res 513:171-174.

Martin LJ, Spicer DM, Lewis MH, Gluck JP, Cork LC (1991) Social deprivation of infant rhesus monkeys alters the chemoarchitecture of the brain: I. Subcortical regions. J Neurosci 11:3344-3358.

Martin LJ, Blackstone CD, Huganir RL, Pricie DL (1992) Glutamate receptors show species differences in the striatum. J Neuropathol Exp Neurol 51:352.

Martin LJ, Blackstone CD, Levey AI, Huganir RL, Price DL (in press) AMPA glutamate receptor subunits are differentially distributed in rat brain. Neuroscience, in press.

McGeer EG (1989) Excitatory amino acids and Alzheimer's disease: idle thoughts on an exciting project. Neurobiol Aging 10:614-616.

Mesulam M-M, Mufson EJ (1984) Neural inputs into the nucleus basalis of the substantia innominata (Ch4) in the rhesus monkey. Brain 107:253-274.

Mesulam M-M, Mufson EJ, Wainer BH, Levey AI (1983a) Central cholinergic pathways in the rat: an overview based on an alternative nomenclature (Ch1-Ch6). Neuroscience 10:1185-1201.

Mesulam M-M, Mufson EJ, Levey AI, Wainer BH (1983b) Cholinergic innervation of cortex by the basal forebrain: cytochemistry and cortical connections of the septal area, diagonal band nuclei, nucleus basalis (substantia innominata), and hypothalamus in the rhesus monkey. J Comp Neurol 214:170-197.

Mesulam M-M, Mufson EJ, Levey AI, Wainer BH (1984) Atlas of cholinergic neurons in the forebrain and upper brainstem of the macaque based on monoclonal choline acetyltransferase immunohistochemistry and acetylcholinesterase histochemistry. Neuroscience 12: 669-686.

Monaghan DT, Cotman CW (1982) The distribution of $\left[{ }^{3} \mathrm{H}\right]$ kainic acid binding sites in rat $\mathrm{CNS}$ as determined by autoradiography. Brain Res 252:91-100.

Monaghan DT, Yao D, Cotman CW (1984) Distribution of $\left[{ }^{3} \mathrm{H}\right]$ binding sites in rat brain as determined by quantitative autoradiography. Brain Res 324:160-164.

Monaghan DT, Bridges RJ, Cotman CW (1989) The excitatory amino acid receptors: their classes, pharmacology, and distinct properties in the function of the central nervous system. Annu Rev Pharmacol Toxicol 29:365-402.

Monyer H, Sprengel R, Schoepfer R, Herb A, Higuchi M, Lomeli H, Burnashev N, Sakmann B, Seeburg PH (1992) Heteromeric NMDA receptors: molecular and functional distinction of subtypes. Science 256:1217-1221.

Moriyoshi K, Masu M, Ishii T, Shigemoto R, Mizuno N, Nakanishi S (1991) Molecular cloning and characterization of the rat NMDA receptor. Nature 354:31-37.

Nakajima Y, Nakajima S, Obata K, Carlson CG, Yamaguchi K (1985) Dissociated cell culture of cholinergic neurons from nucleus basalis of Meynert and other basal forebrain nuclei. Proc Natl Acad Sci USA 82:6325-6329.

Novelli A, Reilly JA, Lysko PG, Henneberry RC (1988) Glutamate becomes neurotoxic via the $N$-methyl-D-aspartate receptor when intracellular energy levels are reduced. Brain Res 451:205-212.

Olney JW (1991) Excitotoxicity and neuropsychiatric disorders. In: Glutamate, cell death and memory (Ascher P, Choi DW, Christen Y, eds), pp 77-101, Berlin: Springer.

Olton DS, Wenk GL (1987) Dementia: animal models of the cognitive impairments produced by degeneration of the basal forebrain cholinergic system. In: Psychopharmacology: the third generation of progress (Meltzer HY, ed), pp 941-953. New York: Raven.

Page KJ, Everitt BJ, Robbins TW, Marston HM, Wilkinson LS (1991) Dissociable effects on spatial maze and passive avoidance acquisition and retention following AMPA- and ibotenic acid-induced excitotoxic lesions of the basal forebrain in rats: differential dependence on cholinergic neuronal loss. Neuroscience 43:457-472.

Parent A (1986) Comparative neurobiology of the basal ganglia. New York: Wiley.

Pavlides C, Greenstein YJ, Grudman M, Winson J (1988) Long-term potentiation in the dentate gyrus is induced preferentially on the positive phase of theta-rhythm. Brain Res 439:383-387.

Petralia RS, Wenthold RJ (1992) Light and electron immunocytochemical localization of AMPA-selective glutamate receptors in the rat brain. J Comp Neurol 318:329-354.

Price DL, Kitt CA, Struble RG, Whitehouse PJ, Cork LC, Walker LC (1985) Neurobiological studies of transmitter systems in aging and in Alzheimer-type dementia. Ann NY Acad Sci 457:35-51

Price DL, Martin LJ, Blackstone CD, Huganir RL (1992) Glutamate receptors show species differences in the basal forebrain magnocellular complex. J Neuropathol Exp Neurol 51:337.

Puckett C, Gomez CM, Korenberg JR, Tung H, Meier TJ, Chen XN, Hood L (1991) Molecular cloning and chromosomal localization of one of the human glutamate receptor genes. Proc Natl Acad Sci USA $88: 7557-7561$.

Robinson GB (1986) Enhanced long-term potentiation in rat dentate gyrus by coactivation of septal and entorhinal inputs: temporal constraints. Brain Res 379:56-62.

Rogers SW, Hughes TE, Hollmann M, Gasic GP, Deneris ES, Heinemann S (1991) The characterization and localization of the glutamate receptor subunit GluR1 in the rat brain. J Neurosci 11:27132724.

Schatz CR, Geula C, Morecraft R, Mesulam M-M (1990) Some species differences of the cholinergic basal forebrain in rat and monkey. Soc Neurosci Abstr 16:1095.

Schwarcz R, Pricc DL (1991) The role of excitotoxins in experimental systems and in human neurological disorders. In: Dahlem workshop reports: life sciences research report, New biological approaches to neurological disorders: pathogenesis and treatment (Price DL, Thoenen $H$, Aguayo AJ, eds), pp 21-34. Chichester: Wiley.

Segal M (1986) Properties of rat medial septal neurones recorded in vitro. J Physiol (Lond) 379:309-330. 
Sommer B, Keinänen K, Verdoorn TA, Wisden W, Burnashev N, Herb A, Köhler M, Takagi T, Sakmann B, Seeburg PH (1990) Flip and flop: a cell-specific functional switch in glutamate-operated channels of the CNS. Science 249:1580-1585.

Verdoorn TA, Burnashev N, Monyer H, Seeburg PH, Sakmann B (1991) Structural determinants of ion flow through recombinant glutamate receptor channels. Science 252:1715-1718

Walaas I, Fonnum F (1980) Biochemical evidence for glutamate as a transmitter in hippocampal efferents to the basal forebrain and hypothalamus in the rat brain. Neuroscience 5:1691-1698.

Walker LC, Price DL, Young WS III (1989) GABAergic neurons in the primate basal forebrain magnocellular complex. Brain Res 499: 188-192.

Watkins JC, Krogsgaard-Larsen P, Honoré T (1990) Structure-activity relationships in the development of excitatory amino acid receptor agonists and competitive antagonists. Trends Pharmacol Sci 11:2533.

Wenk GL, Markowska AL, Olton DS (1989) Basal forebrain lesions and memory: alterations in neurotensin, not acetylcholine, may cause amnesia. Behav Neurosci 4:765-769.

Wenthold RJ, Yokotani N, Doi K, Wada K (1992) Immunochemical characterization of the non-NMDA glutamate receptor using subunitspecific antibodies. J Biol Chem 267:501-507.

Werner P, Voigt M, Keinänen K, Wisden W, Seeburg PH (1991) Cloning of a putative high-affinity kainate receptor expressed predominantly in hippocampal CA3 cells. Nature 351:742-744.
Whitehouse PJ, Price DL, Clark AW, Coyle JT, DeLong MR (1981) Alzheimer disease: evidence for selective loss of cholinergic neurons in the nucleus basalis. Ann Neurol 10:122-126.

Whitehouse PJ, Price DL, Struble RG, Clark AW, Coyle JT, DeLong MR (1982) Alzheimer's disease and senile dementia: loss of neurons in the basal forebrain. Science 215:1237-1239.

Wilson FAW, Rolls ET (1990) Learning and memory is reflected in the responses of reinforcement-related neurons in the primate basal forebrain. J Neurosci 10:1254-1267.

Woolf NJ, Eckenstein F, Butcher LL (1984) Cholinergic systems in the rat brain: I. Projections to the limbic telencephalon. Brain Res Bull 13:751-784.

Wozniak DF, Stewart GR, Finger S, Olney JW, Cozzari C (1989) Basal forebrain lesions impair tactile discrimination and working memory. Neurobiol Aging 10:173-179.

Záborszky L, Léránth C, Heimer L (1984) Ultrastructural evidence of amygdalofugal axons terminating on cholinergic cells of the rostral forebrain. Neurosci Lett 52:219-225.

Záborszky L, Heimer L, Eckenstein F, Léránth C (1986) GABAergic input to cholinergic forebrain neurons: an ultrastructural study using retrograde tracing of HRP and double immunolabeling. J Comp Neurol 250:282-295.

Zaczek R, Hedreen JC, Coyle JT (1979) Evidence for a hippocampalseptal glutamatergic pathway in the rat. Exp Neurol 65:145-156. 